\title{
DISCURSOS E PRÁTICAS À VOLTA DAS ÁRVORES E SUAS UTILIDADES
}

\author{
ÁLVARO CAMPELO ${ }^{(1)}$
}

Resumo:

A relação entre paisagem, árvore e o uso da madeira está ligada ao sentido de cada árvore na imaginação colectiva, e na utilidade que essa árvore tem para os artefactos da vida quotidiana. Há uma clara associação entre as características de cada árvore, a cultura simbólica e o uso da sua madeira. Por sua vez, o uso desta madeira não pode ser feito sem te em conta os sentidos mágico-religiosos que a árvore tem na cosmologia da comunidade. O objectivo deste artigo é tratar o sentido da árvore na paisagem, o seu simbolismo e o uso de certas madeiras no Noroeste Peninsular, nos artefactos do quotidiano.

Palavras-chave: Árvore, Paisagem, Rituais e árvores sagradas, Cosmologia, Artefactos e madeira

\begin{abstract}
:
Discourses and practices around trees and there utilities

The relationship between landscape, tree and the use of wood reflects the perception of each tree in the collective imagination, and the utility that it has in everyday artefacts. There are clear associations between the characteristics of each tree, cultural symbolism, and the use of its wood. However, the usefulness of the wood cannot be turned off a magic-religious sense that tree have in a community cosmology. The aim of this paper is to relate the sense of the tree in landscape, their symbolism, and the use of certain woods in Northwest Iberia, in the artefacts of everyday life, with ethnographic objectives, and the rituals associated with its ownership for human communities.

Keywords: Trees, landscape, Rituals and sacred trees, Cosmology, Artefacts and wood
\end{abstract}

\section{INTRODUÇ̃̃̃O}

O interesse científico, de várias áreas, pelo habitar um espaço natural, pelas práticas sociais, vida comunitária e construção de uma identidade cultural, a partir da paisagem e da organização territorial, tem vindo a aumentar (COSGROVE \& DANIEL 1988; ATRAN 1990; SCHAMA 1995; CASEY 1998; BlOCH 1998; LAURA 1998; ATKINSON et al 2005; INGOLD 2000, 2005; MEUSBURGER et al 2011; CAMPELO 2010, 2013). No caso da antropologia, as relativamente recentes aportações das pesquisas sobre a relação entre natura e cultura (DESCOLA 1994, 2005; MACNAGTEN \& URRY 1998; DesCOLA \& INGOLD 2014), entre a prática do espaço, corpo, mente e conhecimento (BATESON 1980; Gould \& White 1986; CERTEAU 1990; NASH 1996; DRAGAN 1999; DARBY 2000; CAMPELO 2004; JACOBS 2006; MARCHAND 2010), obriga a uma diferente abordagem, tanto da antropologia e da etnografia, como a uma maior interdisciplinaridade nessa abordagem, que vão desde a geografia, a psicologia, a ecologia, as neurociências, a biologia, etc. (INGOLD 2000, 2005, 2011; LOW \& LAWRENCE-ZÚNIGA 2003; DESCOLA 2005; HIRSCH \& O'HANLON 2005). Por sua vez, a arqueologia, está cada vez mais interessada em dar 'identidade' social e cultural aos seus 'terrenos' de pesquisa, acrescentando às 'evidências' materiais, narrativas de leitura que as contextualizem numa paisagem e num território social e cultural (cf. GERRITSEN 2003; DAVID \& TOMAS 2008; HABERLE \& DAVID 2012).
A cultura contemporânea, os novos estilos de vida, e as filosofias que os fundamentam, estão a dar um papel novo à natureza (SERRES 1990; LATOUR 1991; WILSON 1992). Também o estudo das árvores, das florestas e da paisagem, no contexto das ciências sociais, tem vindo a ser cada vez mais frequente desde a década de 1990 (HARRISON 1992; SCHAMA 1995; RACKHAM 1996; RIVAL 1998; MUIR 2000; JONES \& CLOKE 2002; JONAS \& CloKe 2002; Simard 2003; Hageneder 2009). Para além das características naturais, estudadas pela botânica, uma árvore adquire, numa determinada sociedade e num determinado território, um conjunto de sentidos (ligados ao mundo simbólico) e de usos (ligados ao mundo prático e utilitário) que decorrem, fundamentalmente, de três factores: i. as características físicas que têm (a sua morfologia); ii. as possibilidades que essas características apresentam perante as comunidades que as rodeiam, satisfazendo as necessidades quotidianas de recursos e de domínio do espaço onde vivem; iii. os valores associados ao mundo cultural das comunidades.

As árvores adquirem, também, sentidos e simbologias que decorrem da associação que, por vezes, é feita com o homem. A idade da árvore, o seu vigor, vida e morte, etc., servem como exemplificação. Mas os conceitos de 'árvore da vida', 'árvore cósmica', 'centro do mundo', símbolo de fertilidade e de regeneração, são constantes em muitas das culturas humanas (cf. ELIADE 1978, 1987; Chevalier \& CheERBRANT 1982: 62-68;

(1) Universidade Fernando Pessoa - CEAA. Email: campelo@ufp.edu.pt 
BURKET 2001; GODELIER 2015). Associados a estes conceitos, surgem mitos e lendas, onde a presença de uma determinada árvore é parte fundamental para o entendimento das narrativas (MozZANI 1995: 99- 118). A floresta, por sua vez, é frequentemente associada ao conceito de santuário (CHEVAliER \& CHEERBRANT 1982: 455; ALMEIDA 1984: HolM \& BOWKER 1999).

A presença de uma árvore na paisagem é mais do que a constatação de um recurso, seja ele estético, seja o de fornecimento de alimento ou de madeira. Isolada ou em conjunto, ela define a organização do espaço e exige uma relação interactiva. Um dos aspectos mais interessantes das árvores monumentais, de grande duração, é a capacidade que elas têm de fazerem uma ligação entre o passado e o presente, dando consistência história a um espaço ecológico, exigindo o envolvimento do homem nesse legado histórico (GARNER 2004; JONES \& CLOKE 2002). A morfologia, a história, com as estórias associadas, e o lugar que ocupam na paisagem, são activos significativos na rede de práticas e necessidades sociais e ecológicas de uma comunidade (RACKHAM 1998). Da compreensão do lugar que ela ocupa no espaço e das possibilidades do seu uso, nascem saberes, técnicas e um conhecimento simbólico, para maximizar, no interesse da comunidade, a relação que esta estabelece com a árvore, levando Garner (2004) a falar da relação entre a identidade de uma comunidade e a sua cultura material. Enquanto bosque ou floresta, as árvores 'pensam-se' e 'vivem-se' como um todo, um mundo simbólico complexo, onde o espaço ou território adquirem sentidos mais abrangentes, integrando os elementos que os constituem, sejam eles reais (outros elementos físicos, biológicos, orográficos, etc.), sejam fictícios ou do mundo do imaginário (duendes, seres fantásticos, forças e energias invisíveis, etc.). Quando isoladas, o papel que as define na paisagem depende de vários factores: i. o seu porte e morfologia distintiva (altura ou largura, composição dos ramos); ii. a sua vetustez reconhecida; iii. a raridade da sua espécie, entre as que a circundam; iv. a qualidade dos seus frutos ou madeira; v. ou o facto de serem, enquanto árvores, raras na paisagem (paisagens desérticas ou de alta montanha), e daí a sua importância, mesmo que não tenham características físicas relativamente notórias.

Quando estas características são evidentes, as comunidades humanas acrescentaram, para além dos utilitários, outros sentidos. Sentidos que implicam e comprometem a cultura das comunidades, fazendo uma dupla transferência, ou seja, trazer para o seu mundo social e cultural as qualidades físicas das árvores, servindo-se delas e com elas exprimirem as suas próprias emoções e o seu mundo simbólico. Ou, então, transferir os anseios e medos humanos para as árvores, ritualizando a relação com elas, colocando nelas e nos espaços que as envolvem a oportunidade de solucionarem a relação com o mistério da natureza, da vida, e com o mundo espiritual invisível (DAVIES 1988).

A árvore, ou o bosque, apresentam-se como uma referência, 'lugar praticado' (CERTEAU 1990), seja a nível de material utilitário, seja simbólico. $\mathrm{Na}$ história da cultura humana (se nos é permitido reduzir com tanta simplicidade o que significará 'cultura humana'), várias foram as sociedades que utilizaram a simbologia da árvore para tratar do sentido do mundo. A árvore representa a vida, o conhecimento, o elemento intermediário para 'ligar' os três mundos que conformam a maioria das cosmologias: o mundo subterrâneo, o terrestre e o celeste. No primeiro penetram as raízes, no segundo assenta o tronco, no terceiro projectam-se os ramos. É assim que a árvore representa o mundo e o mundo se representa numa árvore (CHEVALIER \& CHEERBRANT 1982)!

Alguns dos nossos contributos, neste trabalho, para entendermos a relação que as comunidades estabelecem com as árvores, resultam de muitos anos de trabalho de terreno, realizado por nós na região do Noroeste Peninsular (Portugal e Espanha). Ao longo de muitos trabalhos de campo, nomeadamente na recolha de narrativas lendárias (Campelo 1999) e, na observação e estudo de rituais e práticas culturais (CAMPELO 2004, 2010, 2013), foi-nos permitida uma aproximação às apropriações que estas comunidades fazem dos espaços florestais e dos bosques, bem como do papel de cada espécie arbórea no quotidiano e no seu mundo simbólico.

\section{A ÁRVORE COMO REPRESENTAÇÃO DO MUNDO}

É de conhecimento geral, de quem trabalha o campo dos rituais e dos mitos (cf. ElIADE 1987; FRAZER 1982), o facto de, ao longo da história, os povos terem assumido a árvore como um símbolo da vida e do conhecimento. A simbologia da árvore vai desde os conceitos de 'árvore-pai' ou 'árvoremãe', e 'árvore-antepassado' (donde surge a árvore genealógica - (Fig.1) - onde prevalecem os sentidos de vida, gestação e origem - , aos conceitos de 'árvore central', presença ou sinal do lugar donde e para onde se orientam as forças vitais do espaço comunitário, pela sua força de propagação ou pela atracção dessas forças, de 'árvore da vida' e 'árvore do mundo', na medida em que representa a vida (alimenta e cura), ou representa a plenitude cósmica e a diferenciação entre o mutável e o imutável (Frazer 1982; CHEVALIER \& CHEERBRANT 1982; CoAgrove \& DANIEL 1988; CASEY 1998; GARNER 2004; HAGENEDER 2009).

O cosmos está organizado entre as forças da criação, da vitalidade e da morte. Este é o mundo experienciado pelas pessoas, a necessitar de ser representado e ritualizado constantemente. Assim, as árvores de folha caduca, que se revestem de 
folhas cada ano, dentro do ciclo natural, são a representação da regeneração, da contínua mutação da natureza. Esta natureza, modificando-se, mantém-se, no entanto, a mesma, num ciclo contínuo, dando segurança aos que presenciam essas mutações. Por sua vez, as árvores de folhas persistentes estão associadas à imortalidade (CHEVALIER \& CHEERBRANT 1982). Altera-se a natureza, o clima, modificam-se as estações do ano, mas as folhas persistem nos ramos das árvores, provando que nem tudo acaba, cai e morre. Então as árvores são a prova de um mundo que tanto se regenera pela morte, como pela permanência da vida (HUMBOLT 1884; EliADE 1978). Este é um mundo passível de ser vivido e compreendido, pois a experiência dos homens mostra como a morte é uma realidade e o desejo da imortalidade um direito a não perder ${ }^{1}$.

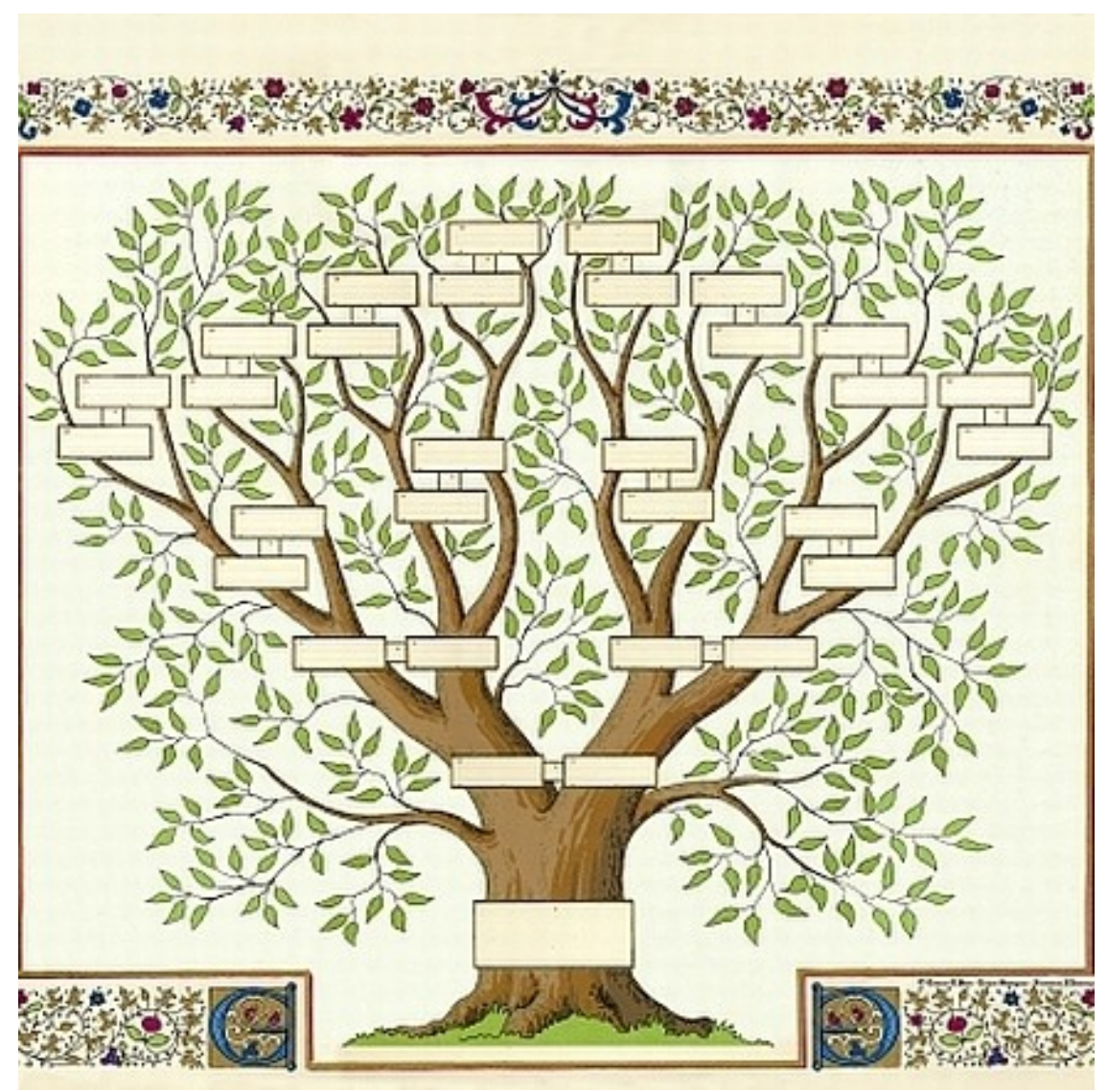

Fig. 1. A árvore como representação de filiações e dependências. Genealogias de famílias, ideias e organizações.

Fig. 1. Tree representation of affiliations and dependencies. Genealogies of families, ideas and organizations.

Nos rituais de representação deste mundo conhecível e desejável, evocam-se as qualidades físicas da árvore, para falar da 'evolução biológica', entre a vida e a morte, os símbolos da fertilidade, e, até, a dualidade sexual, que está na sua origem. São tantos os rituais de fertilidade celebrados junto de árvores sagradas ou utilizando ramos ou varas de árvores e até suas figurações (FRAZER 1982; MozZANi 1995). Ramos que se introduzem na terra e florescem de vida, transpondo para o ofertante ou para toda a comunidade, a vida que se quer ver nascer ou a vida que se quer celebrar (DRAGAN 1999) (Fig. 2). A árvore encerra os dois elementos sexuais que estão na origem da vida: a ramagem feminina onde penetra o tronco, símbolo da virilidade masculina. Mas quando a esterilidade é evidente, na vara nua e morta, o mundo uterino é o da mãe terra, onde penetra essa vara estéril, germinando em frondosa vida. Desta forma, a árvore da vida, primordial árvore cósmica, coloca em comunicação os três mundos da nossa cosmologia, organizando-os, e é muitas vezes comparada ao 'axis mundi', que sustenta e equilibra o universo (ELIADE 1987). São estas categorias de 'árvore da vida' e de 'axis mundi' (Fig. 3) que sustentam os sentidos invocados nos rituais celebrados à volta de

${ }^{1}$ Sem querermos entrar aqui pela simbologia sagrada do cristianismo, não deixamos de referir como a cruz, onde os cristãos representam a morte de Cristo, mais do que uma 'árvore da morte', é, para a teologia cristã, uma 'árvore da vida', pois a partir dela surge a ressurreição, ou seja, a vida! 
certas árvores sagradas, troncos totémicos ou, até, bosques sagrados (MOZZANI 1995). Na antiguidade (e até nos tempos medievais) surgiram santuários próximos destes locais onde as árvores da vida' eram celebradas ${ }^{2}$. O santuário cristaliza, de alguma forma, esse 'espaço centro do mundo', onde se pode ter contacto com a eternidade, de onde nasce tudo e onde é possível ter acesso, porque é o eixo vivo do mundo, a outras dimensões ou mundos. Essa árvore organiza o espaço e serve para instaurar na terra a cidade paradisíaca futura: "No meio da praça da cidade e sobre as duas margens do rio, encontram-se as árvores da vida, que frutificam doze vezes, dando fruto a cada mês; $e$ suas folhas servem para curar as

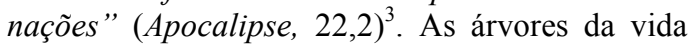
ladeiam o "rio de água da vida"(Apocalipse, 22,1 ), a força do conhecimento, associado ao Espírito que brota de Deus, segundo a simbologia bíblica. Retoma-se, assim, a árvore do paraíso perdido. Nesse primeiro paraíso, a árvore da vida estava junto da árvore do conhecimento, regadas pelo rio do jardim do Éden: "Deus fez crescer do solo toda a espécie de árvores formosas de ver e boas de comer, e a árvore da vida no meio do jardim, e a árvore do conhecimento do bem e do mal" (Génesis, 2,9) ${ }^{4}$. Os frutos da árvore do conhecimento estavam proibidos a Adão e Eva. Prevaricar esta ordem levava ao castigo, pela morte. No Apocalipse já só estão as árvores da vida, elas mesmas a fonte do conhecimento, porque representam, com a água do rio, o Espírito que dá vida. Daí o sentido do pleno conhecimento, plena vitalidade, a cura eterna, que a partir de agora a

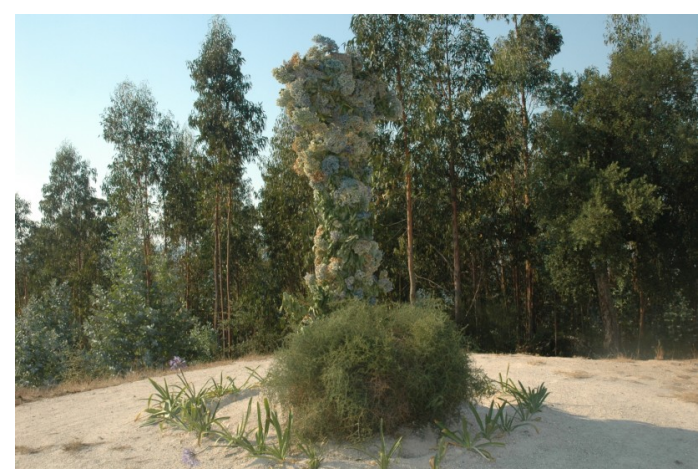

Fig. 2. A Cruz florida. Cruz 'árvore da vida'. Fonte Arcada Penafiel.

Fig. 2. Cross decorated with shrubs and flowers, ' tree of life '. Fonte Arcada - Penafiel. árvore da vida terá. E o mesmo se diga do poder de todas as árvores sagradas, no final de contas, quando ritualizadas, mesmo pelas religiões não cristãs. É debaixo de uma árvore (a árvore de Bodhi) que Siddharta Gautama (que já havia nascido debaixo de uma árvore), despertou (Buda significa 'o despertado' ou 'o iluminado') para a verdade da condição humana, num estado de suprema libertação, o 'nirvana', onde não há qualquer impedimento ao conhecimento (MOZZANI 1995). Assim, a árvore sagrada dá a plenitude do conhecimento e liberta dos males atribuídos à contingência da condição humana. A associação entre árvore e conhecimento pode ser vista na língua celta e nas línguas germânicas, onde os termos aprender, saber, e sabedoria são parentes próximos dos termos floresta e árvore (por exemplo "Buche" - faia, "Buch" - livro) (CHEVAliER \& CHEERBRANT 1982).

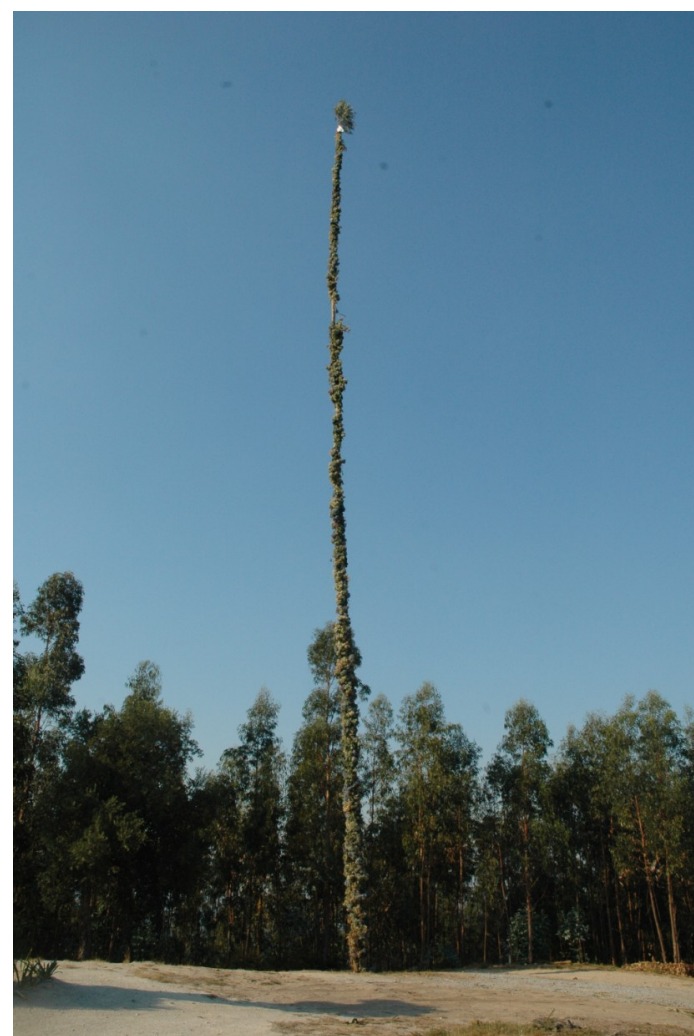

Fig. 3. O madeiro levantado. Uma árvore cortada e transportada por homens, marca o centro da terra e a virilidade. Fonte Arcada - Penafiel.

Fig. 3. A tree cut and carried by men, is the center of the Earth and sign of virility.

\footnotetext{
${ }^{2} \mathrm{Na}$ religião shinto do Japão, os templos primitivos eram as próprias árvores. Com o tempo, foram acrescentados altares às árvores, e não o contrário. Parece que o mesmo aconteceu no ocidente, como relata Escalante (EsCALANTE, M. F. 1979. Paganismo en Cantábria, en los umbrales de la edad barroca, Seminário del departamento de filosofia del derecho de la Universidad de Valência), quando se refere a um texto do século XVI de Villafañe, que, por sua vez, nos dá conta de um facto dos finais do século XVI: uns missionários jesuítas encontraram em pleno coração do território cantábrico, nos montes de Paz, comunidades não cristianizadas que adoravam um carvalho. Não havendo templos, os missionários reuniam ali junto do carvalho as pessoas das redondezas para pregar. Após a morte de um dos missionários, as pessoas, em sua homenagem, construíram um altar junto ao carvalho. Mostra este exemplo como se fez em muitos lugares a sacralização cristã de antigos lugares de culto ancestrais.

${ }^{3}$ Textos retirados da tradução portuguesa da edição Bíblia de Jerusalém, publicada pela ‘École Biblique de Jérusalem”, em 1973.

${ }^{4}$ Nas diferentes traduções, há, por vezes, a interpretação de que a árvore da vida é a mesma da árvore do conhecimento. Ou, ainda, que há uma só árvore da vida (no centro da praça), e não várias árvores da vida, que ladeiam o rio da água da vida.
} 
Olhando agora, e num outro registo simbólico e iconográfico (mais contemporâneo, mas já utilizado nas árvores genealógicas), para a forma da árvore, desde as raízes, passando pelo tronco, até às ramificações da sua copa, ela (morfologia da árvore) contribuiu para comunicar e elucidar o sentido de organizações complexas, ou seja, está associada, mais uma vez, à transmissão de uma mensagem, ao conhecimento! A maior parte destas representações esquemáticas, de variadíssimos aspectos e até com sofisticados ícones, esquece as raízes, pois a centralidade da coesão da instituição ou do projecto que se quer comunicar, está na força do tronco, donde derivam as acções, os agentes, ou os propósitos que se pretendem enunciar (Fig. $4 \mathrm{e}$ Fig. 5). Umas vezes mais figurativas, ou mais próximas das representações naturais da árvore, outras vezes mais esquemáticas ou abstractas, onde prevalecem linhas que partem de um canal convergente (o tronco), para ramificações sucessivas, a distinguir por cores e ícones, as árvores gráficas comunicam com mais ou menos eficácia. A instituição ou ideia a comunicar segue a forma da árvore, multiplicando os ramos conforme a complexidade e variedade dos conteúdos.

Mais uma vez, a árvore mostra a organização de 'um mundo' (seja ele o de uma instituição ou de uma conteúdo conceptual) a partir de um tronco comum, do qual se forma uma rede de conexões, uma mensagem em rede, mimética à ramagem da árvore natural. Ramificações, dependências, hierarquias, familiaridades ou distinções, sucedem-se, formando a 'ideia' ou a 'estrutura' daquilo que é propósito comunicar. Não é possível este 'mundo' funcionar ou ter sentido, sem que a rede comprometa e posiciona correctamente cada uma das partes. A árvore comunica e dá conhecimento sobre aquilo que comunica.

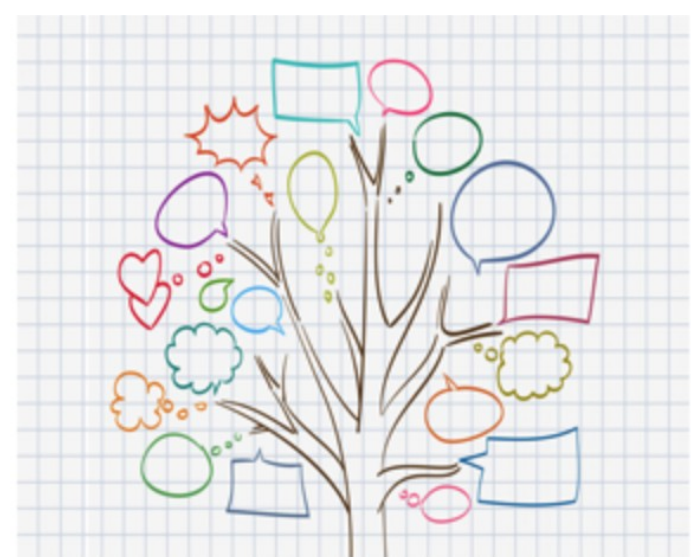

Fig. 4. Árvore esquemática. O mundo organiza-se em rede de mensagens.

Fig. 4. Schematic tree. The world is organized in network ideas.
Durante milhares de anos a madeira foi a 'matéria prima' por excelência e ainda o é em muitas sociedades, seja na percentagem utilizada para construção e fabrico de objectos, seja no prestígio do seu uso. Não deixa de ser interessante que haja, em muitas línguas, uma relação clara entre 'madeira' e 'ciência'! Em grego, a palavra 'HYLÉ, que designa literalmente madeira, tem o mesmo sentido de 'matéria prima'! De matéria prima, a partir da qual se fazem objectos, artefactos utilitários, construções (desde as casas aos santuários), a elemento sobre o qual se age para demonstrar saber, arte, técnica, poder, estatuto social, a madeira aproxima-se do ponto de encontro entre a matéria e o conhecimento ${ }^{5}$. Daí que nos países nórdicos a árvore e a madeira tivessem o mesmo sentido de ciência. Nelas (árvore e madeira) se procurava a sabedoria que estava no divino, não sendo de estranhar que a madeira, também aqui, se transfigure em 'árvore do conhecimento', 'lugar' onde se encontra o espiritual, a fonte de cura e de sabedoria, e o 'lugar' onde se expressa a sabedoria, de que a acção artística é exemplar incontornável (MOZZANI 1995). Tocar a madeira (tocar as árvores) é um ritual de protecção ou desejo de sorte, recorrentemente praticado em muitas culturas (Boussel 1969; PanAti 1989). Possuir determinada madeira ou ramo de determinada árvore traz felicidade, sorte ou protecção aos perigos (ANDRADE 1989).

Algumas das primeiras armas utilizadas pelos humanos (lanças, arcos e flechas) foram de madeira, ou utilizaram-na. A partir do Neolítio, começa uma extraordinária modulação da paisagem, com o início das construções em madeira nos espaços de

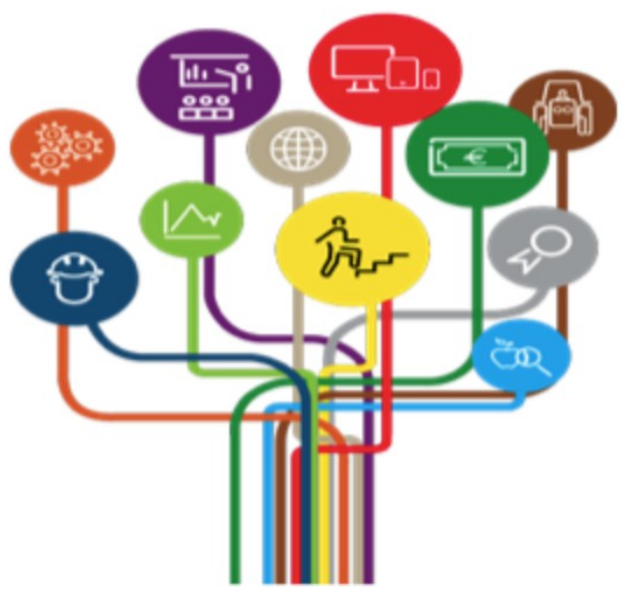

Fig. 5. Árvore esquemática. Uma sociedade organizada em rede de profissões

Fig. 5. Schematic tree. A society organized in network of professions.

${ }^{5} \mathrm{Na}$ cultura suméria o 'espírito da árvore' é ' $E a$ ', deus da sabedoria, que ofereceu a cultura, as leis e a moral aos homens. Esta árvore significava a 'casa da sabedoria, força e fartura'. A epopeia de Gilgamesh (GILGAMESH 1999) (cf. BonNEFoy 1981) fornece elementos abundantes sobre as qualidades desta árvore. Não nos podemos esquecer que é na fonte desta cultura suméria que surge a mitologia presente no Livro do Génesis, particularmente o relato do dilúvio. 
residência, funerários e cerimoniais. Na Pré-história Recente, a necessidade de aproveitamento da madeira para estes fins despoletou um maior conhecimento das possibilidades de utilização dos materiais das árvores, que nunca foi desprezada (antes pelo contrário) quando se afirmou o uso dos metais. Os humanos desenvolvem um domínio do trabalho da madeira, conforme as qualidades das mesmas, nos seus ecossistemas, com uma crescente habilidade (a 'skill' de Tim Ingold: 2000; 2011). É essa crescente habilidade que implica uma focagem não já apenas nos objectos, mas naquilo que as pessoas fazem com os objectos ('coisas' para Ingold) e assim realizam 'a vida', o conhecimento que situa essa 'coisa' num campo de relações, que obriga a uma atenção já não no objecto, mas nos 'fluxos vitais', não na matéria, mas nos 'fluxos de materiais' (INGOLD 2011). É esta utilidade, domínio das técnicas de a trabalhar, focagem nos processos de transformação na dinâmica de uso dos materiais e dos objectos, a sua inserção na vida das pessoas, junto com a valorização simbólica da árvore e das densas florestas, que faz com que a relação dos homens com as árvores ultrapasse meramente o abrigo e o comer as suas folhas ou frutos. Lentamente, o homem vai aprender a proteger, a cuidar e a alimentar as árvores, principalmente aquelas que trouxe para junto do espaço de residência, integrando-as na sua própria vida. Devemos entender que a introdução dos objectos em madeira ('coisas') na vida das comunidades, alterou para sempre a sua percepção e acção no mundo, porque eles não são matérias, objectos e formas disponíveis, acabadas, mas integrantes no tal 'fluxo vital' ('fluxo de materiais') que nos coloca em relação, diferentemente, com um mundo vivo e dinâmico. Esse 'fluxo de materiais' coloca em acto uma progressiva especialização na acção, um conhecimento, pois ao incluir o grupo e o espaço neste fluxo, mostra como toda a 'construção de conhecimento' é um processo de interacção entre interlocutores e praticantes, num meio ambiente (MARCHAND 2010).

A partir do momento da expansão da agricultura, verifica-se um aumento da representação das árvores, base de uma mitologia sobre as plantas, que se transformam e renascem, ao mesmo tempo que marcam o espaço residencial sagrado, donde surgem os mitos sobre a criação da humanidade, os deuses da fertilidade. Osíris, no Egipto, descansa na acácia (Acacia nilotica); nos mito de Adão e Eva, é o fruto de uma árvore, a do conhecimento, que decide a história da humanidade. $\mathrm{O}$ mesmo se diga do papel do teixo (Taxus baccata) na mitologia na Eurásia (HAGANEDER 2009). Não é por acaso que muitos talismãs fabricados em madeira asseguram a protecção, a guarda de uma energia vital e do conhecimento (Andrade 1989). Veja-se também os casos do uso da madeira de bétula (Betula pendula; Betula pubescens; Betula celtibera ) para os berços, camas e pingentes para as crianças (porque tinha o papel da protecção, verificando-se que a runa germânica para esta árvore, berkana, significava 'maternidade, protecção') (HAGENEDER 2009).

Raros são os povos que não têm a sua 'árvore sagrada', ou até o seu bosque sagrado (com tipologia diferenciada, segundo o contexto ecológico ou o ecossistema em que vivem) ${ }^{6}$. Há árvores que, pelas suas próprias características e pela importância que têm (em muitos âmbitos) para a sobrevivência da comunidade, adquirem, por si mesmas, este papel espiritual. Daí que, em cada cultura, um número muito restrito e bem determinado de árvores assuma este estatuto. James Frazer (1982), que descreve as múltiplas crenças e rituais religiosos perante as árvores, fala do papel sagrado do carvalho (de diferentes espécies Quercus), à volta do qual se colocavam lâmpadas e se faziam ofertas. Nos carvalhos mais velhos, com fendas e troncos ocos, as pessoas passavam por entre as fendas e penetravam o tronco (também o dos castanheiros) onde se procurava a cura para certas doenças e uma mudança de vida, quando a sorte era adversa (MozZANI 1995). Ao acto de penetrar na fenda e no tronco oco, trespassar o tronco, dava-se o sentido do renascimento do corpo, como se saísse, novamente, de uma cavidade uterina para o mundo.

Mas convém salientar que, mais importante do que a árvore em si mesma, o que importa é o que se passa na relação da comunidade com essa árvore, ou seja, a nova realidade que se manifesta nessa relação, presente na árvore, o 'espírito' que lhe dá a vida, e nela se manifesta. Ao procurar-se a árvore, usufrui-se da força protectora desse espírito, da sua energia vital, da sua sabedoria. Em muitos lugares, a árvore 'abriga' um espírito divino. E há um claro sentido de relação entre a 'hospitalidade' da árvore a este 'espírito' e a 'hospitalidade' da árvore àquele que procura a sua sombra (CHEVALIER \& CHEERBRANT 1982).

Após esta sucinta explanação sobre a simbologia da árvore, não estranha que a prevalência, entre os cultos naturalistas (às árvores, às pedras, à água - fontes e nascentes), o das árvores seja um dos mais populares, de que a veneração dos bosques (Sébillot 2002) é uma extensão. Foi contra este culto que se debateu o cristianismo romano, principalmente nos territórios anteriormente classificados de bárbaros. Disso dão prova muitas das decisões de concílios regionais e o famoso livro de S. Martinho de Dume, De correctione rusticorum (Da Correcção dos rústicos), do século

\footnotetext{
${ }^{6}$ Por vezes, mudando as condições climáticas, ou por migrações, os povos escolhem uma outra 'árvore da vida' (que representa a vida em si mesma) ou 'árvore do mundo' (representa a plenitude do universo). Veja-se a transferência de veneração do cedro, na Assíria, para a tamareira) (cf. BONNEFOY 1981).
} 
VI, com o propósito de des-demonização da natureza ${ }^{7}$. Houve, então, uma 'cristianização' dos lugares sagrados, assentando cruzes e altares junto destas árvores sagradas, como já referenciamos. Também a tradição oral colocou junto delas a 'aparição' de imagens sagradas, de santos, etc.. Em covas escavadas junto destas árvores viveram eremitas. Estas habitações precárias deram origem, mais tarde, a cenóbios, ermidas, conventos e santuários (ALMEIDA 1984; PEREIRA 2005). Inicia-se toda uma reinterpretação destes lugares, no alto dos montes ou junto às nascentes e bosques, com narrativas e lendas, onde acontecimentos fantásticos e milagrosos se sucedem, desde os de aparecimento de neve em pleno Agosto (e o surgimento de capelas à Senhora das Neves), até aos 'bastões floridos', sinais de uma regeneração do espaço e da santidade do portador, marca do início de uma tradição. Não raro é associado a estes bosques sagrados qualidades extraordinárias, como, por exemplo, o de terem temperaturas e aromas fora do comum, convidando às manifestações santas ou amorosas (DETIENNE 1972).

Uma outra perspectiva de análise ao papel da árvore e do bosque (floresta) na paisagem, está no eles ocuparem uma função específica no ordenamento do espaço e na definição dos sentidos do seu uso. Em primeiro lugar, este ordenamento faz, desde já, uma distinção entre o 'selvagem' e o 'doméstico'. Quando as espécies arbóreas não foram plantadas segundo as estratégias de ocupação dos espaços agrários disponíveis e não produzem frutos que entrem na dieta alimentar das sociedades agrícolas (apesar de haver frutos silvestres muito importantes em certas dietas), surgindo espontaneamente nestes espaços ou dentro de bosques, a relação estabelecida com estas espécies é a de um aproveitamento dos seus produtos, mas que não exigem o cuidado e a atenção dispensada no trabalho quotidiano ou sazonal. A floresta e bosque onde estas árvores vivem, não sendo classificados imediatamente como selvagens, adquirem, no entanto, esse sentido, pois são deixados às vicissitudes climatéricas, a um ordenamento relativamente caótico e a demais riscos, como se a sua sobrevivência decorresse não do trabalho e programação humana, mas das potencialidades endógenas do ecossistema que formam. Isso não significa que, dentro deste bosque ou floresta, não surjam determinadas árvores que, pelas suas extraordinárias características, sejam destacadas e valorizadas, diferentemente, pela comunidade ${ }^{8}$. Como um todo, este bosque ou floresta desordenada, que se preserva por sua própria força, adquire sentidos e usos que o aproximam das expectativas associadas ao perigo (DOUGLAS 1991), ao mundo selvagem, à vitalidade do conjunto, a um espaço carregado de elementos mágicos, misteriosos e, até, temíveis.

Mas, numa outra perspectiva, dentro do espaço agricultado, o espaço domesticado, a árvore é um elemento cuja presença define esse espaço. Fálo individualmente ou em conjunto, desde que esse conjunto seja mais ou menos homogéneo. Temos assim um pomar, um souto, um olival, um laranjal, etc. Mesmo no espaço doméstico surgem árvores que, não produzindo qualquer fruto, têm outra função: estética, fornecimento de sombra, ostentação de status social da casa, etc.. A presença destas árvores é fundamental para os habitantes da casa, para os residentes e todos os praticantes desse espaço. A contribuição para o embelezamento do espaço e para exprimir o estatuto social da casa, está tanto na beleza intrínseca da forma da árvore, dos seus ramos, folhas e possíveis flores, como na raridade da mesma, o que explica a adopção de espécies exóticas em muitos dos jardins e espaços envolventes à casa, como veremos. As árvores de fruto, por sua vez, contribuindo com um produto alimentar sazonal, funcionam como um regulador do tempo, ao qual se associam, para além dos cuidados esperados e das colheitas expectáveis, narrativas, festividades, estórias e acontecimentos vividos. Há árvores de fruto que ficam mais próximas, no quintal das casas, e outras que bordejam campos e estão mais afastadas. Essa geografia espacial botânica é também uma geografia emocional, de afectos, como se o que está no 'centro' do jardim ou quintal ocupasse o 'centro' da atenção e dos cuidados especiais. As árvores de fruto são sempre as que mais se aproximam dos espaços residenciais, só superadas pelas que são plantadas com fim estético e de sombra, junto à casa. Não estranha, assim, que em muitas

${ }^{7}$ S. Martinho de Dume, De Corretione Rusticorum. [16]:

"Nam ad petras et ad arbores et ad fontes et per trivia cereolos incendere, quid est aliud nisi cultura diaboli? Divinationes et auguria et dies idolorum observare, quid est aliud nisi cultura diaboli? Vulcanalia et Kalendas observare, mensas ornare, et lauros ponere, et pedem observare, et fundere in foco super truncum frugem et vinum, et panem in fontem mittere, quid est aliud nisi cultura diaboli? Mulieres in tela sua Minervam nominare et Veneris diem in nuptias observare et quo die in via exeatur adtendere, quid est aliud nisi cultura diaboli? Incantare herbas ad maleficia et invocare nomina daemonum incantando, quid est aliud nisi cultura diaboli? Et alia multa quae longum est dicere. Ecce ista omnia post abrenuntiationem diaboli, post baptismum facitis et, ad culturam daemonum et ad mala idolorum opera redeuntes, fidem vestram transistis et pactum quod fecistis cum deo disrupistis. Dimisistis signum crucis, quod in baptismum accepistis, et alia diaboli signa per avicellos et sternutos et per alia multa adtenditis. Quare mihi aut cuilibet recto Christiano non nocet augurium? Quia, ubi signum crucis praecesserit, nihil est signum diaboli. Quare vobis nocet? Quia signum crucis contemnitis, et illud timetis quod vobis ipsi in signum configitis.

${ }^{8} \mathrm{O}$ conceito de 'bosque selvagem' necessita de uma avaliação critica, dado ele estar cada vez mais estudado em outras zonas climáticas, como a das florestas húmidas tropicais. Desde os trabalhos de Hans ter Steege et al. (2013) e de Derrell Posey et al. (1995; 2006), por exemplo, entende-se diferentemente o 'espaço selvagem' da amazónia, onde foi possível provar que a floresta que hoje conhecemos, com a distribuição e ocorrência de determinadas árvores de fruto (e outras de elevado valor para o quotidiano dos povos que aí habitam) são consequência da actividade humana. Há, assim, uma 'organização' da paisagem por parte das comunidades. A floresta que qualificamos de 'selvagem' é um património cultural herdado, 'plantada' pelos seus habitantes. O mesmo se pode dizer das florestas e bosques do nosso espaço em análise, pois na sua aparência, caótica e 'selvagem', escondem práticas e estratégias de interesse comunitário bem utilitárias aos seus usuários. Uma história das nossas paisagens florestais dá-nos a prova disso mesmo (cf. SiLVA 2007). 
culturas hajam rituais associados à vida familiar que integrem as árvores de fruta ${ }^{9}$.

A prática de corte das árvores, para delas obter madeira ou outros produtos, com objectivos específicos para o indivíduo ou comunidade, obedece a esta diferenciação da localização das árvores. Em primeiro lugar, cortar árvores na floresta ou bosque, não é a mesma coisa que as cortar junto do espaço doméstico e agrado para sustento da família. Na floresta procura-se a árvore, selecciona -se a mais adequada ao fim proposto, sabendo que a árvore vetusta regenerará nas mais novas, ali ao lado. Há a consciência de que o bosque se apresenta como um todo, que não sendo evidentemente homogéneo, vive das interdependências e da sua própria condição de conjunto ${ }^{10}$. Daí o nascer de uma consciência de que o bosque ou floresta tem uma identidade vital em si mesmo, onde o conceito de bosque sagrado se concretiza. A veneração a uma árvore, que enquanto veneração individual está ligada à madeira, transfere-se para a veneração ao bosque sagrado, que no seu todo adquire o poder do mistério e do respeito. Muitos povos (cf. DESCOLA 1994; 2005), antes de cortarem uma árvore, rezam aos espíritos, para os apaziguarem, pois reconhecem-se membros de mesmo mundo que, alterando-o, alteram a sua própria vida. Associa-se, assim, a vida da árvore à vida da pessoa e da comunidade. Mas não deixa de ser interessante ver a ambivalência da floresta, pois ao mesmo tempo que é sagrada, fonte de vida, ela é também (e talvez por isso) um local problemático, onde a obscuridade, os ruídos, fazem supor ou atraem actos e práticas extraordinárias (CAMPELO 2004). Entre a força da vida e a angústia do desconhecido, a floresta e o bosque fomentam a veneração (HARRISON 1992).

Neste papel de ordenamento espacial, e consequente valorização por parte da comunidade, surgem aquelas árvores que, singularmente, se destacam na paisagem, próximas ou distantes ao espaço residencial. Essa evidência singular atrai o olhar, a atenção da comunidade e não pode passar despercebida aos discursos de interpretação do território, donde surgem os rituais de apropriação e construção das vivências comunitárias. Na geografia mundial, cada ecossistema tem as árvores de excepção de que já falamos. Quando elas marcam um espaço, se singularizam ou formam um conjunto surpreendente, não raro são sacralizadas, valorizadas e sujeitas a práticas especiais de protecção e celebração. E sendo elas sacralizadas, sacralizam, por sua vez, o espaço que ordenam, os lugares onde se evidenciam. Estas árvores adquirem para as comunidades um tal valor e poder que, a partir das vivências e rituais que presenciam, da memória de eventos e narrativas que carregam, transformam -se em memória comunitária, porque marcam definitivamente a memória do espaço, enquanto espaço vivido (VAYA 1969; RODMAN 1992; MEUSBURGER et al. 2011; MIDDLETON \& BROWN 2011). As investigações recentes mostram como a presença ou ausência de uma destas árvores interfere no mundo cognitivo colectivo e individual, pois o espaço está ordenado, a nível visual e prático, por essa árvore, conferindo-lhe um sentido (cf. JORGENSEN \& STEDMAN 2001; MARCHAN 2010). A perda destas árvores, muito para além da perda botânica e ecológica, é uma perda do património cultural da comunidade. Um perda que pode ter, para as gerações que as viveram, consequências cognitivas, emocionais, desestabilizando a ordem do quotidiano, tida como familiar, e dos momentos excepcionais, tidos como seguros.

Há, como vimos, uma 'utilidade' para cada árvore. Conforme cada uma das suas características, as árvore respondem a finalidades diversas: gastronomia, construção, tinturaria, mobiliário, utensílios domésticos, artefactos agrários, artesanato, produtos medicinais, sombra, prestígio, etc. No que respeita aos fins medicinais, a referência das qualidades de cura das árvores principais são do conhecimento geral, mas a sua manipulação ou o conhecimento de espécies mais sofisticadas, pertence aos especialistas. Este conhecimento advém da transmissão entre famílias ou iniciação ritual, cabendo ao xamã ou curandeiro a sua guarda, manutenção e transmissão. Grande parte do prestígio do xamã ou curandeiro está no ser ele o conhecedor profundo do que cada árvore pode curar, da manipulação dos elementos e da forma e quantidade de os ministrar. Para além das qualidades químicas intrínsecas a cada espécie, cujo conhecimento se sedimenta pela experiência ao longo de gerações, a selecção das espécies de madeira, folhas e frutos, está também ligada ao que chamamos 'efeito de similitude', ou seja, as suas características de cor, forma, dureza, etc., são entendidas como mais ou menos adequadas e eficazes para doenças que apresentam essas mesmas características.

É importante salientar a relação entre a dureza, resistência, durabilidade e características estéticas, da madeira de cada árvore, para entender a selecção do seu uso e o prestígio da posse. Dentro de um determinado ecossistema, as comunidades humanas adquiriram um aprofundado conhecimento destes dados, a partir dos quais maximizam a utilização das madeiras de cada árvore. Se alguma vez procuram espécies exógenas, é porque têm sobre elas um mínimo de conhecimento para delas

\footnotetext{
${ }^{9}$ No cantão suíço de Aargau, uma pereira era plantada no nascimento de uma menina, e se fosse um menino, uma macieira era a árvore de nascimento. Além disso, a macieira foi importante em tradições populares de cortejo da amada, namoro e casamento - um teólogo do século $\mathrm{V}$ tornou a maçã rapidamente em "maçã do pecado", que se chamava no texto original em hebraico sobre o paraíso, apenas 'peri', "fruta", sem identificação botânica (MOZZANI 1995).

"maçã do pecado", que se chamava no texto original em hebraico sobre o paraíso, apenas 'peri', "fruta", sem identificação botânica (MOZZANI 1995).
${ }^{10}$ Há hoje estudos que mostram como as árvores de um bosque 'negoceiam' (através de uma 'comunicação' química) entre si a disponibilidade do espaço e dos recursos, numa 'proxémica' biológica, como um organismo vivo, interdependente, umas vezes solidário, outra vez em competição (cf. SIMARD 2003; SIMARD \& SACHS 2003).
} 
tirarem o proveito que almejam, salientando a excepcionalidade da sua madeira ou do seu valor estético.

\subsection{A árvore no Noroeste Peninsular Ibérico}

O conhecimento que temos de como as comunidades desta região tratavam a natureza e as árvores, chega-nos pelos estudos realizados por etnógrafos e historiadores (VASCONCELOS 1897, 1933-1988; VIVES 1963; ALBERTOS 1974; BAROJA 1950; SCHULTEN 1959; BLÁZQUEZ 1961; GIORDONO 1983; CAMPELO 2004; 2010), mas também pelo célebre livro, anteriormente invocado, de Martinho de Dume, do séc. VI. Algumas das práticas dos povos que aqui habitavam interpretavam a natureza dentro de uma crença que Martinho julgava errónea, e, por isso, de necessária 'correcção', argumentando que nada na natureza é o divino, mesmo que tudo resulta da criação divina (cf. MEIRINHOS 2006: $398^{11}$ ). Estamos muitos séculos distantes da obra de Martinho de Dume, mas muitas das pesquisas realizadas pelos autores citados mostram como prevaleceram os sentidos e a percepção de uma geografia sagrada (ALMEIDA 1984), entretanto transformada pela cristianização dos espaços e, recentemente, pela sua laicização.

Nas pesquisa de terreno que levamos a efeito, não encontramos um culto explicito à árvore sagrada. Encontramos, sim, espaços florestais, grupos de árvores (bosques ou conjuntos de determinadas espécies de árvores), árvores isoladas, com especial protecção e veneração por parte da comunidade e entretanto valorizadas pelo poder administrativo; encontramos rituais e crenças, que só podem ser entendidas e contextualizadas, se percebermos os símbolos anteriormente referidos e o papel que estas árvores, a nível histórico, cultural e prático, tiveram e têm nas comunidades do noroeste peninsular ibérico. O mesmo se diga para a importância do uso da madeira e dos frutos das árvores, da escolha e selecção realizada entre as diferentes espécies autóctones e, até, entre as espécies exógenas, mais ou menos exóticas. Na utilização da madeira, nos trabalhos realizados com ela e sobre ela, encontramos a tal ciência e saber, prova do engenho humano e da extraordinária capacidade para simbolizar, construir sentidos, sociabilidades e estratificação social, para além dos outros sentidos de domínio do espaço, da regulação do poder, seja ele o da autoridade e prestígio social, seja o do poder mágico-religioso.

O mundo lendário desta região (CAMPELO 1999) dá-nos muitas informações dos espaços florestais onde animais fantásticos e mulheres (muita vezes classificadas como bruxas) ocupam um lugar de destaque, com forças sobrenaturais. Passar nestes locais obriga a cuidados especiais e a temores inusitados. Nestes espaços o corpo feminino exerce uma performance entre a marginalidade e a reivindicação de um poder desafiante (CAMPELO 2004; NAPIER 1992; NASH 1996). Ou seja, a excepcionalidade do espaço florestal, de alguma forma estranho à 'normalidade' dos espaços agrários, onde imperava o poder masculino, mostrava-se como o lugar ideal para dar a oportunidade de evidenciar um outro poder: o da mulher e da sua feminilidade. Trata-se de um poder ambivalente, pois tanto dá a conhecer a realidade de um corpo que oferece a vida, como denuncia os perigos e possíveis calamidades, se o corpo se expressa fora desse espaço de eleição, onde o masculino não entra e onde não tem capacidade de negociar o mistério das forças da natureza.

A marca da presença da árvore sagrada está quase sempre associada ao carvalho. Tratando-se de uma árvore autóctone e de grande presença na paisagem desta região do noroeste peninsular, não deixa de, nessa 'banalidade' da presença, evidenciar o extraordinário, pela sua capacidade de vetustez e de marcar, assim, essa paisagem. Os carvalhos centenários são a prova da perseverança da natureza; os ramos frondosos e largos, oferecem-se numa hospitalidade generosa, daí serem, os carvalhos, considerados 'templos' vivos, lugares de hospitalidade, de sabedoria e de força (robus), transformando-se em 'árvores cósmicas'. Estas concepções do mundo são comuns aqui, quando verificamos a omnipresença de santuários e ermidas em lugares onde existem ou existiam grandes carvalhais ou soutos, denunciando como a religiosidade popular se juntou às estratégias da igreja em manter a santificação destes lugares mágicos (ALMEIDA 1984; ElIADE 1987; HOLM \& BOWKER 1999; BURKET 2001; GODELIER 2015). É desta reorganização do espaço sagrado, onde antes imperavam as árvores sagradas, que surgem os conventos e santuários afastados dos locais habituais de residência das comunidades. Se as construções adquiriram ou não a magia que antes a natureza oferecia (PEREIRA 2005), certo é, para os que visitam estes santuários, celebrarem também os espaços adjacentes, onde se abrigam, onde deambulam entre árvores centenárias, acreditando nessa comunhão sagrada e no direito e obrigação de as protegerem (SERRES 1990), dando pleno sentido a todo o espaço envolvente à ermida ou santuário, como se de um só lugar - 'coisa' - se tratasse (TRIFT 1999), com todas as qualidades ecológicas preservadas para a identidade e sentido dos valores que celebram.

${ }^{11}$ Meirinhos (2006) tem ainda o objectivo de mostrar que a obra de Martinho de Dume não é a prova de que nesta área territorial existia uma sociedade 'rústica', fundamentalmente pagã e supersticiosa. O propósito da obra de Martinho é catequético (não etnográfico) e sublinha questões que suscitam a análise teológica e paranética do bispo de Braga. Ou seja, não se estava perante um comportamento geral e uma caracterização sociológica das comunidades, mas sim perante hábitos populares que se repetiam desde há muito tempo e herdados do passado. Era fundamental "eliminar a crença na eficácia da superstição e num mundo animado por espíritos, optando pela crença na racionalidade e unidade da natureza" (MEIRINHOS 2006: 414). 
Mas ainda hoje perseveram árvores que se distinguem no bosque, adquirindo sentidos que ultrapassam em muito a dimensão ecológica. É exemplo disto o famoso carvalho da freguesia de Calvos, no concelho da Póvoa de Lanhoso (Fig. 6). Trata-se de um carvalho-alvarinho (Quercus robur, um dos carvalhos mais comuns na Europa, cf. ICNF 2016) com 23 metros de altura, $40 \mathrm{~m}$ de diâmetro médio da copa, 7,4 $\mathrm{m}$ de diâmetro médio do tronco e um perímetro à altura do peito de 10 metros. A idade da árvore está calculada em mais de 500 anos, segundo consta na informação cedida pelo Centro Interpretativo do Carvalho de Calvos. Há, portanto, novas visões e usos. Se anteriormente passava pelo culto religioso, no presente é a visão patrimonialista e ecológica a que prima, passando pela classificação da árvore como sendo de interesse público, em 22 de Agosto de 1997. Tal proposta deu origem ao Centro Interpretativo, que ocupa uma área de 17 hectares, com edifícios museológicos e de serviços, para a educação ambiental e para o lazer. No entanto, o exemplo que evocamos, o do carvalho de Calvos, mostra-nos ainda a prevalência dos antigos e sempre renovados sentidos mágicos e religiosos ${ }^{12}$. Junto a este local, numa propriedade particular, bem no limite da mesma e na zona mais próxima do carvalho, foi erigido um cilindro de alumínio polido, com cerca 4 metros de altura. Pertence esta propriedade e o objecto a uma organização internacional, cujos membros, vindos de vários países, mas onde prevalecem os de nacionalidade espanhola, segundo os vizinhos, realizam rituais à volta deste cilindro, em certa alturas do ano, numa perspectiva new age da relação dos homens com a natureza.

Eles estão ali às voltas do poste de metal, colocam-se à volta, sei lá, à noite. Acho que acreditam que o mundo pode acabar e é aqui que está o lugar melhor. Não sei se acreditam mesmo no que fazem, se estão a divertirse, ou a rezar! Mas parece gente sem problemas na vida. Há quem diga que são professores, médicos, eu sei lá... artistas... gente que gosta da natureza. O certo é que não gostam muito de serem incomodados. Dizem que aqui há muita energia boa! Isto até é bonito... não fazem mal a ninguém! (Homem, 67 anos, Póvoa de Lanhoso).

Outras espécies de árvores ocupam um lugar especial no imaginário popular e na vida quotidiana das comunidades desta região. Umas valorizam -se pelo seu papel de fornecimento de madeira com alto valor. São os casos do carvalho; do castanheiro (Castanea sativa) ${ }^{13}$; da cerejeira (Prunus avium),

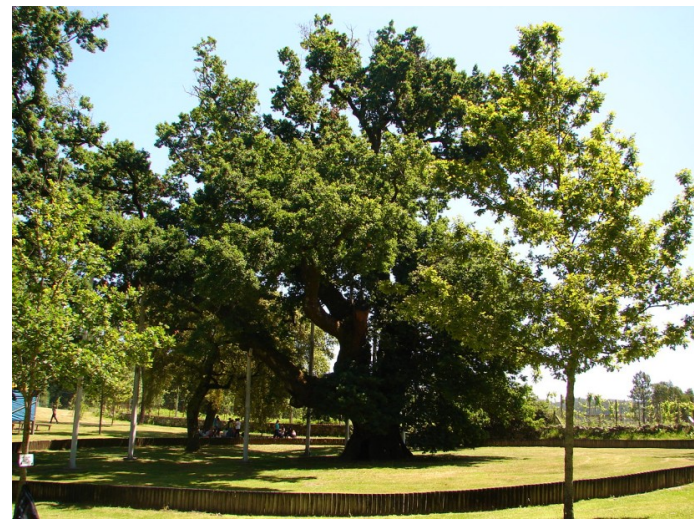

Fig. 6. Carvalho secular. Uma árvore sagrada. Calvos Póvoa de Lanhoso.

Fig. 6. Secular oak. A sacred tree. Calvos - Póvoa de Lanhoso.

que para além de fornecer o fruto, dá uma madeira valorizada pela cor e textura; da nogueira (Juglans regia), que também tinha utilidade para a medicina e a tinturaria. Todos sabemos a importância do pinheiro (pinheiro-bravo: Pinus pinaster; e pinheiro-manso: Pinus pinea) e do eucalipto (outra espécie exógena: Eucalyptus sp.) na manufactura dos artefactos e na construção. Mas, para as pessoas, os móveis de prestígio tinham de ser em 'castanho', de cerejeira, ou, até, de oliveira (muito mais difícil de trabalhar):

Uma cama ou armário em castanho é outra coisa! Duram muito tempo e são seguros. Eu tinha ali uma cama de castanho que o meu filho queimou... dizia que era velha! Agora tenho uma que nem sei se é mesmo de madeira! Mas para os meus filhos é moderna! Esta gente nova não sabe nada de boa madeira.. (Mulher, 84 anos, Arcos de Valdevez).

Pela dificuldade de trabalho e parca disponibilidade de madeira útil para móveis, o carvalho não é tão utilizado como o castanheiro para estes fins. Mas todos queriam a viga de carvalho ou de 'castanho' sobre as quais construíam os sobrados e os tectos das casas. A resistência e durabilidade das suas madeiras eram a promessa da estabilidade e permanência da casa. Sobre e sob estas traves passava a vida das famílias; elas eram a garantia de segurança.

Já para os artefactos agrários, utensílios da casa, tinturaria e fins medicinais, procuravam-se outras árvores e madeiras. As razões estavam na facilidade de trabalho, no tamanho, na flexibilidade, na cor, no cheiro, etc. De facto, valoriza-se o odor e qualidades mágicas ou medicinais, associadas a certas madeiras, por ex.: a do teixo (Taxus

${ }^{12}$ Saliente-se a divindade Drusuna (cf. MozZANI 1995) que era a deusa do Carvalho, protectora das florestas, padroeira da sabedoria druídica.

${ }^{13}$ Proporciona madeira de alta qualidade, apreciada na construção, carpintaria, tanoaria e tiras para cestaria; as castanhas, ricas em hidratos de carbono e com diversas cultivares, são utilizadas para alimentação humana, do gado e na pastelaria. As folhas e casca têm taninos que são úteis no tratamento de hemorragias e diarreia. Uma infusão das folhas é usada para tratamento de febre e tosse convulsiva. 
baccata), de utilidade medicinal e de marcenaria, com seus bosques designados de "teixeiras" ${ }^{14}$; a do freixo $^{15}$ (Fraxinus angustifolia); a do amieiro (Alnus glutinosa), 'rei das águas' e o salgueiro (salix sp.) ${ }^{16}$, 'rainha' das mesmas e suas fadas; a de oliveira (Olea europea), associada à força e à vida; o sobreiro (Quercus suber), o loureiro (Laurus nobilis), com seu uso medicinal e culinário; e, posteriormente, o eucalipto), justificavam preferências. Dado o uso da madeira em tantos momentos da vida quotidiana e em tantas partes das construções (portas, janelas, soalhos, camas, mesas, arcas, utensílios da cozinha, etc.), ou ainda nas ornamentações das festas, nas cercas dos campos ou nas cancelas dos 'eidos', seleccioná-las e trabalhá-las, obrigou a um saber a que poucos dos camponeses se podiam alhear, dado o regime de autarcia em que viviam. $\mathrm{O}$ aumento da qualidade dos artefactos e a inscrição nesses artefactos de regras e programas artísticos muito elaborados, denunciam uma valorização estética do objecto, uma busca do prestígio social, pela visibilidade pública que a maioria deles tinha (cangas de gado, portas, artefactos para trabalhar o linho, etc.), mas são já a prova da especialização, da existência de um número de pessoas que domina o trabalho da madeira, os marceneiros, que, agora, passam a servir uma clientela mais exigente. Se ao valor próprio de cada madeira é acrescentado um outro valor, como o estético, os objectos adquirem tal relevância social que não podem mais serem vistos como meros utensílios domésticos e agrários (daí o facto de muitos deles ocuparem hoje prateleiras de museus).

As espécies arbóreas apresentam-se, como vimos, individualmente e em conjunto. Enquanto conjunto, estas espécies formam, no noroeste ibérico, como que um 'marcador espacial', ou seja, relacionam-se não apenas como um 'sítio florestal'17, mas como um 'sítio florestal' apropriado pela comunidade, que lhe atribui, pelas características ecológicas que tem, determinadas qualidades ambientais, utilitárias, e sentidos sociais e transcendentais ou mágicos. Estes 'sítios florestais' funcionam como 'lugares' para procurar bens e para práticas rituais, como fronteiras, para relações espaciais, como referências visuais para organizar o território habitado ou praticado. Assim sendo, é nas suas proximidades que se iniciam os processos de nuclearização dos habitats (e mesmo a sua fortificação), bem como os processos de territorialização do espaço, onde não seriam estranhos os lugares sagrados e as construções monumentais, que mais tarde dariam origem aos santuários cristãos como já referimos. Não estranha, portanto, que junto com uma perda da mancha florestal, decorrente da exploração intensiva por parte dos grandes povoados da Idade do Ferro, nas áreas circundantes ao seu núcleo, como provam os estudos paleoambientais (RAMIL-REGO \& AIRA RODRIGUEZ 1996), prevaleçam 'sítios florestais' de grande valor ecológico até anos bem próximos de nós. Cumpriam outras funções, não opostas à necessidade de aumentar áreas agrícolas. Assim chegaram até nós os soutos, os pequenos sítios florestais ligados a muitos dos santuários de montanha e de vale, nesta região. A dado momento, a destruição pela actividade humana e pelos fogos, fez com que, à volta destes santuários, nascessem parques florestais organizados, com as espécies autóctones, e valorizados (no sentido estético) pela introdução de espécies exógenas.

A árvore apresenta-se ainda, nesta região, como um factor de prestígio social. São exemplo disto as árvores colocadas nos jardins ou próximo das casas. Se os nossos românticos salientam os carvalhos e suas sombras, que protegem, junto da casa, os residentes, o velho pai, ou os casais amorosos (muito frequente, por ex., em Camilo Castelo Branco), quando olhamos para a paisagem dos quinteiros das casas dos lavradores e, principalmente, para os jardins das casas senhoriais, verificamos a permanência de algumas espécies que estão ali para testemunharem a riqueza e o prestígio da casa. É o caso das Camélias (Camellia sp.), (também designadas popularmente de 'japoneiras', denunciando a origem das mesmas e uma espécie em particular, a Camellia japonica), que ora aparecem isoladas junto da casa do lavrador rico, ou em grandes conjuntos, em jardins de camélias, nas casas armoriadas, cercada pelo buxo (Buxus sempervirens), trabalhado em topiária. $\mathrm{O}$ mesmo se diga da Araucária (Araucaria angustifolia) vinda do Brasil (pinheiro do Paraná - Curi, nome indígena), mais rara, mas, por isso mesmo, salientando mais o prestígio da casa; ou, ainda, a Palmeira Imperial (Roystonea oleracea), originária das Antilhas, que depois de ir para o Brasil, veio também para Portugal. Estas árvores exógenas são a expressão da riqueza e prestígio da casa, não só pela beleza exótica que ostentam, e pelo facto de não terem outra utilidade, que não a estética, mas também porque, de alguma forma, trazem para junto da casa familiar a história de alguns membros dessa família que viajaram ou construíram fortuna nas terras do oriente ou do Brasil. No meio urbano, da província, ou no meio rural mais isolado, elas

\footnotetext{
${ }^{14} \mathrm{O}$ teixo que se conhece como sendo o mais antigo de Portugal, classificado, tem cerca de 700 anos, é o Teixo de Tranguinha e situa-se em Bragança.

${ }_{15}^{15}$ Árvore mítica em muitas culturas da Europa, dado o deus Ebúrio estar associado ao freixo e bosques em geral, também chamado Eburianos (MOZZANI 1995).

${ }^{16} \mathrm{O}$ salgueiro é na mitologia romana uma árvore consagrada à deusa Juno e tinha propriedades para deter hemorragias, ou, ainda, para evitar o aborto. De salientar que é da sua casca que se retira produto para fazer a aspirina, como prova o nome, 'ácido acetilsalicílico, ou seja, de 'salix' (MOZZANI 1995).

${ }^{17}$ Pode-se definir 'sítio florestal' como um conjunto de factores físicos e fisiográficos, climáticos, biológicos e edáficos, que caracterizam uma determinada área e definem as suas características ecológicas. Alguns dos 'sítios florestais' de grande qualidade ecológica são os também denominados 'sítios higrófilos' ou seja, locais onde a posição topográfica favorece a acumulação de água de origem freática, que se soma à proveniente da precipitação, originando maiores disponibilidades hídricas para as plantas. Ocorrem tipicamente na base de paredes rochosas, em locais onde o nível freático se aproxima ou contacta com a superfície e no fundo dos vales ou em bacias endorreicas, com drenagem insuficiente.
} 
comunicam mundos diferentes, destacando-se entre a paisagem circundante. E ao destacarem-se, destacam a 'casa' (no sentido mais lato do que se entende aqui por casa familiar) na paisagem e na estrutura social.

\section{O CARVÃO}

Nas comunidades do noroeste, o carvão tem várias simbologias. Ele é tanto a expressão de um fogo que se consumiu (e daí expressar o fim ou o exaurimento de uma vitalidade - 'reduzido a carvão' - o que se sentia aquando dos incêndios que reduziam a cinza as habitações das pessoas), como, pela cor que ostenta (cinzento ou negro), referenciar (ao contrário do fogo) a escuridão, o negrume, e um mundo próximo das forças cósmicas 'escuras' (associadas por vezes ao diabólico ou maléfico). Em muitos dos rituais do 'Entrudo', por ocasião da celebração das festas carnavalescas, é frequente pintar ou simplesmente 'sujar' os rostos com carvão. O mesmo se fazia nos rituais de fim de ano ou celebração do 'ano velho', querendo com isso mostrar, no primeiro ritual, uma manifestação do caos e da anormalidade permitida pelo Entrudo, alterando a ordem social que exige a limpeza, e, no segundo ritual, acentuar as características do homem velho, pelo fim do ano velho, e a necessidade do surgimento de um outro ciclo de vida.

Mas há uma outra área mais ambígua, no sentido simbólico, que surge tanto da utilização do carvão, para dele voltar a acender o lume e conseguir energia, como da presença dele em algumas das lendas desta região. Desde a lareira onde restam as cinzas e os carvões, onde cada dia se reacendia a fogueira do lar, até à forja do ferreiro, o carvão mantinha-se sempre ligado ao calor e ao fogo. Guardar os carvões das fogueiras extintas ou produzir carvão, com os métodos dominados pelos CARVOEIROS $^{18}$, era uma das estratégias de gestão dos recursos energéticos das comunidades. Em algumas lendas por nós levantadas nesta região (CAMPELO 1999) é frequente a presença de carvões. Os carvões são dados, pelas Mouras, a crianças ou jovens, aos quais é solicitado que os conservem por um determinado tempo, para que, depois, sejam compensados pela guarda dos mesmos. Não raro os jovens desprezam o que lhes é oferecido pela Moura, dado o desprezo que dão a um material sem valor e, para além disso, em pouca quantidade (três, cinco, sete carvões). Sinal desse desprezo é o lançar fora os carvões oferecidos! Mas aqueles, poucos, que os conservam, são surpreendidos, passados dias, ao encontrarem, na gaveta ou mala onde os guardaram, não os pedaços negros e sem valor dos carvões, mas pedaços, do mesmo tamanho, em ouro resplandecente! Estas lendas tinham o propósito de chamar a atenção dos mais jovens para o valor de coisas que, aparentemente, não o têm, mas que, na realidade, podem vir a manifestar uma incontornável importância.

Como eram frequentes as 'queimadas', para conquistar terra cultivável ou para libertar espaço florestal aos percursos dos rebanhos, as comunidades sempre tiveram os carvões das árvores e dos arbustos como fazendo parte do ciclo da vida. Se eles evidenciavam a morte e a destruição, eram também a promessa de boas sementeiras e bons pastos. O convívio com o carvão era tão familiar, que podia ser apropriado para os sentidos mais variados, conforme o interesse momentâneo. No entanto, a perda de uma árvore importante para a comunidade, pelo fogo, tendo em conta os sentidos e usos anteriormente referidos, para além da perda económica, era sinal de mau presságio.

\section{CONCLUSÃO}

A importância utilitária, simbólica e paisagística das árvores mostra-nos como uma aproximação aos usos e práticas da árvore e seus derivados é extraordinariamente preciosa para entendermos a cultura de uma comunidade. Dado serem estas práticas e rituais tão significativos para a estabilidade social da comunidade, sua sustentabilidade ecológica e sobrevivência no espaço territorial que dispõe, estudá-los permite-nos adquirir ferramentas para o conhecimento das mesmas, de uma forma que outros instrumentos e evidências não o fazem.

A conciliação dos estudos etnográficos, contextualizados na investigação antropológica comparativa da cultura humana, com as pesquisas arqueológicas, cada vez mais interessadas pelas evidências das madeiras e carvões encontrados nos seus terrenos de pesquisa, darão, certamente, um maior espaço de interpretação destas evidências. A presença de uma ou outra árvore, de uma espécie de bosque, próximo ou distante de um assentamento humano, manifestado pela evidência da sua madeira ou dos seus carvões, dará informação preciosa para a contextualização das construções e de outras evidências materiais ali escavadas. Não é razoável uma extrapolação imediata dos sentidos das comunidades actuais, estudadas pelos etnólogos e trabalhadas pelos antropólogos, para as comunidades do passado, mais ou menos longínquo. No entanto, as formas de apropriação do território, de dar sentido ao espaço habitado, de estratificar a sociedade e negociar com a natureza disponível, pela abundância e pela raridade, os sentidos da vida, do extraordinário, das fronteiras e, principalmente, das urgentes necessidades de sobrevivência, não serão assim tão diferentes, historicamente, no mundo cognitivo das comunidades humanas.

\footnotetext{
${ }^{18}$ Grupos de famílias especializavam-se neste mester, dando, inclusive, o nome da arte ao lugar onde habitavam. O seu domínio das técnicas de construção dos
} sistemas de queima de lenha e produção de carvão que perduravam por gerações. Um domínio que certamente foi útil para o cozimento de cerâmica. 


\section{BLIOGRAFIA}

AlBertos, M. L. 1974. El culto a los montes entre Galaicos, Astures y Berones. Estúdios de Arqueologia Alavesa, 6: 147-157.

Almeida, C.A.F. de. 1984. Religiosidade Popular e Ermidas. Studium Generale, $\mathrm{n}^{\circ}$ 6: 75-83.

ANDRAde, M.- O. 1989. Les Porte-Bonheur. Paris: C. Bonneton.

AtKinson, D.; JACKSON, P.; Sibley, D. AND Washbourne, N. [ed.s]. 2005. Cultural Geography. A Critical Dictionary of key Concepts. London: I.B. Tauris.

Atran, S. 1990. Cognitive Foundations of Natural History. Cambridge: Cambridge University Press.

BAteson, G. 1980. Mind and Nature: a necessary unity. London: Fontana/Collins.

BAROJA, C. J. 1950. Sobre el culto a los árboles y la mitologia relacionada con él en la Península Ibérica Homenagen a D. Luís de Hoyos Sainz, Vol. II, Madrid: 65-74

BLÁZQUeZ, J. M. 1962. Religiones primitivas de Hispânia, I: Fuentes Literárias y epigráficas. Madrid: S/E.

Bloch, M. 1998. Why Trees, Too, Are Good to Think With Towards an Anthropology of the Meaning of Life. In L. Rival (ed.). The Social Life of Trees. Oxford: Berg.

BonNEFOY, Y. [dir.]. 1981. Dictionnaire des Mythologies et des Religions des societés traditionnelles et du monde antiqúe. Paris: Flammarion.

Boussel, P. 1969. Manuel de la superstition. Paris: La Palatine.

BRAdLey, R. 1997. Rock Art the Prehistory of Atlantic Europe: Signing the Land. London, New York: Taylor \& Francis e-Library.

BURKET, W. 2001. A criação do sagrado. Lisboa: Edições 70.

CAmpelo, A. 2013. A Paisagem. Introdução a uma gramática do Espaço.. Guimarães: UMDGEO - Departamento de Geografia da Universidade do Minho.

CAMPElo, A. 2010. "Espaço, construção do mundo e suas representações". In Bettencourt, A. \& Alves, L. (eds.). Dos montes, das pedras e das águas. Formas de interacção com o espaço natural da pré-história a actualidade. Braga, CITDEM / APEQ, pp. 191-206.

CAMPElo, A. 2004. As viajantes da noite: celebrar o corpo nas margens e encruzilhadas da vida. In ANA TOSCANO \& Shelley Godsland (orgs.). Mulheres Más. Percepção e representações da mulher transgressora no mundo luso-hispânico. Porto: Edições UFP, pp. 15-32.

Casey, E. S. 1998. The Fate of Place. A Philosophical History. Berkeley and London: University of Califórnia Press.

Certeau, M. de. 1990 (1980). L'invention du quotidian. 1. Arts de faire. Paris: Gallimard.

Chevalier, J. \& Cheerbrant, A. 1982 (1969). Dictionnaire dês Symboles. Mythes, rèves, coutumes, gestes, formes, figures, couleurs, nombres. Paris: Robert Laffont / Júpiter.

Colaço, M. C. (Coord.). 2011. Floresta, Muito Mais que Árvores. Manual de Educação Ambiental para a
Floresta. Lisboa: Autoridade Florestal Nacional.

Cosgrove, D. E. 1984. Social Formation and Symbolic Landscape. Madison, Wisconsin: The University of Wisconsin Press.

Cosgrove, D. E. \& DANIEL, S. (ed.s). 1988. The Iconography of Landscape. Cambridge: Cambridge University Press.

Costa Tenorio, M.; Morla Juaristi, C.; SaInz Ollero, H. 2005. Los bosques ibéricos. Una interpretación geobotánica. 4.a Ed. Barcelona: Editorial Planeta, S.A.

DARBY, W. J. 2000. Landscape and Identity. Oxford, New York: Berg.

DAVID, B. \& TomAs, J. (ed.s). 2008. Handbook of Landscape Archaeology. Walnut Creek: Left Coast Press.

DAviES, D. 1988. The Evocative Symbolism of Trees. In COSGROVE et al. [ed.s] The Iconography of Landscape. Cambridge: Cambridge University Press.

Delumeau, J. 1994. Uma história do paraíso. Lisboa: Terramar.

DesCOLA, PH. 2005. Par-delà nature et culture. Paris: Gallimard.

DesCOLA, PH. 1994. In the Society of Nature: a native ecology in Amazónia. Cambridge: Cambridge University Press.

Descola, PH. \& IngOLD, T. 2014. Etre au monde. Quelle experience commune? Lyon: Presses Universitaires de Lyon.

Detienne, M. 1972. Les Jardins d'Adonis. La mythologie dês aromates en Grèce. Paris: Gallimard.

DRAGAN, R. 1999. La représentation de l'espace de la société traditionnelle. Les mondes renversés. Paris: L'Harmattan.

Douglas, M. 1991. Pureza e perigo, Lisboa: Ed. 70

ELIADE, M. 1978. O Mito do eterno retorno. Lisboa: Edições 70

Eliade, M. 1987. Le sacré et le profane. Paris: Gallimard.

FrAZER, J. 1982. O Ramo de Ouro. Rio de Janeiro: Editora Guanabara [edição original de 1890: The Golden Bough; a Study in Magic and Religion]

GARDNER, A. 2004. Living history. Trees and Metaphors of identity ina an English Forest. JOurnal of Material Culture. Vol. 9(1): 87-100.

GERRITSEN, F. 2003. Local Identities. Landscape and community in the late prehistoric Meuse-Demer-Scheld Region. Amsterdam: Amsterdam University Press.

GILGAMESH. 2007 [Séc. VII a. c.]. Lisboa: Nova Vega (Tradução de Pedro Tamen, Prefácio e ilustrações de Luís Alves da Costa).

Giordonol, O. 1983. Religiosidad Popular en la Alta Edad Media. Madrid: Gredos.

GODELIER, M. 2015. L'imaginé, l'imaginaire \& le symbolique. Paris: CNRS Éditions.

Gould, P. \& White, R. 1986. Mental Maps. London: Penguin Books.

Haberle, S.G. \& David, B. (ed.s). 2012. Peopled Landscapes. Archaeological and biogeographic ap proaches to landscapes. Canberra: The Australian National University.

Hageneder, F. 2009. El Legado de los Árboles: Historia cultura y simbolismo, Santiago de Chile: Columba. 
HARrison, R. P. 1992. Forest: The Shadow of Civilisation. Chicago, IL: Chicago University Press.

Hirsch, E. \& O’Hanlon, M. (eds.). 2005. The Anthropology of Landscape: Perspectives on Place and Space. Oxford: Oxford University Press.

Holm, J. \& Bowker, J. 1999. Lugares Sagrados. Lisboa: Edições Europa - América.

HumBolt, A. 1884 (1850). Views of Nature: or contemplations on the Sublime Phenomena of Creation. With Scientific Illustrations. London: George Bell and Sons.

ICNF. 2016. Espécies arbóreas indígenas em Portugal Continental. Guia de Utilização. Lisboa: Instituto da Conservação da natureza e das Florestas, I.P.

INGOLD, T. 2011. Being Alive. Essays on movement, knowledge and description. London / New York: Routledge.

INGOLD, T. 2004. Beyond biology and culture. The meaning of evolution in a relational world. Social Anthropology, v. 12, n. 2: 209-221.

IngOLd, T. 2000. The Perception of the Environment. Essays in livelihood, dwelling and skill. London: Routledge.

JACOBS, M. H. 2006. The production of mindscapes: A comprehensive theory of landscape experience. $\mathrm{PhD}$ thesis, Wageningen University.

Low, S. \& Lawrence-Zúniga, D. 2003. The Anthropology of Space and Place: Locating Culture. Malden, MA: Blackwell.

Jones, O. \& Cloke, P. 2002. Tree Cultures: The Place of Trees and Trees in Their Place. Oxford: Berg.

Jorgensen, B. S. \& Stedman, R. C. 2001. Sense of place as an attitude: Lakeshore owners attitudes toward their properties. Journal of Environmental Psychology, 21, pp. 233-248.

LATOUR, B. 1991. Nous n'avons jamais été modernes. Essai d'anthropologie symétrique. Paris: La Découverte.

LAUrA, R. (Ed.). 1998. The Social Life of Trees: Anthropological Perspectives on Tree Symbolism. Oxford: Oxford University Press.

Macnagten, Ph. \& URry, J. 1998. Contested Nature. London: Sage.

MARCHAND, T. H. J. 2010. Making knowledge: explorations of the indissoluble relation between minds, bodies, and environnment. Journal of the Royal Anthropological Institut, S1-S21.

MARTINHO DE DuME, S. 1997 (séc. VI). Instrução pastoral sobre superstições populares. De Correctione Rusticorum. Edição, tradução, introdução e comentários de Aires A. Nascimento, com a colaboração de Maria João V. Branco. Lisboa: Cosmos.

MEIRINHos, J. F. 2006. Martinho de Braga e a compreensão da natureza na alta Idade Média (séc. VI): símbolos de fé contra a idolatria dos rústicos. In Estudos em Homenagem ao Professor Doutor José Marques. Porto. Faculdade de Letras da Universidade do Porto, pp. 395-414.

Meusburger, P.; Michel Heffernan; Edgar Wunder (ed.s). 2011. Cultural Memories. The Geographical Point of View. Dordrecht, Heidelberg, London, New York: Springer.

Middleton, D. \& Brown, S. D. (ed.s). 2011. Memory and Space in the Work of Maurice Halbwachs. In Peter
Meusburger et al (Eds.) Cultural Memories. The Geographical Point of Wiew. Heidelber, London and New York: Spring.

Mozzani, É. 1995. Le Livre dês Superstitions. Mythes, Croyances et Legendes. Paris: Robert Laffont.

MUIR, R. 2000. The new reading the landscap: Fieldwork in landscape history. Exeter: University of Exeter Press.

NASH, C. 1996. Reclaiming vision: looking at landscape and the body. Gender, Place and Culture, 3 (2): 149-169.

NePIER, A.D. 1992. Foreign bodies. Performance, art and symbolic anthropology. Berkely: University of California Press.

PANATI, C. 1989. L'Origine merveilleuse dês choses de tous les jours. Paris: Éditions First.

PereirA, P. 2005. Enigmas: lugares mágicos de Portugal. Lisboa: Círculo de Leitores.

Posey, D. A.; Argumedo, A.; DA Costa E Silva, E.; DutField, G.; Plenderleith, K. 1995. Indigenous peoples, traditional technologies and equitable sharing: international instruments for the protection of community intellectual property and traditional resource rights. Gland, Switzerland: International Union for the Conservation of Nature.

Posey, D. A. \& BALICK, M. J. (Eds.). 2006. Human Impacts on Amazonia: The Role of Traditional Ecological Knowledge in Conservation and Development. New York: Columbia University Press.

RACKHAM, O. 1996. Trees and Woodland in the British Landscape. London: Phoenix.

Ramil-Rego, P.; Aira Rodriguez, M. J. 1996. Antropización y desarrollo agrícola en el N. O. Peninsular, a partir de análisis polínicos y paleocarpológicos. Bot. Macaronésica. 23: 269-283.

Rodman, M. 1992. Empowering Place: Multilocality and Multivocality. American Anthropologist, 94(3): 640 -656 .

Schama, S. 1995. Landscape and Memory. New York: Knopf.

SÉBILlOT, P. 2002 (1904-1906). Croyances, mythes et légendes des pays de France, établi par Francis Lacassin. Paris: Éditions Omnibus..

SERres, M. 1990. Le Contrat naturel, Paris: François Bourin.

SILVA, J. S. (Coord.). 2007. Árvores e Florestas de Portugal. Lisboa: Público, Comunicação Social, SA, Fundação Luso-Americana para o Desenvolvimento e Liga para a Proteção da Natureza. Coleção de 9 volumes.

SIMARD, S.W.; SACHS, D.L. 2003. Assessement of interspecific competition using relative height and distance índices in an age sequence of seral interior cedarhemlock forests in British Columbia. Canadian Journal of Forest Research, 34 (6): 1228-1240.

SChulten, A. 1959. Geografia y Etnografia antiguas de la Península Ibérica, Madrid: Instituto 'Rodrigo Caro' de Arquelogía.

SteEge, H. Ter et al, 2013. Hyperdominance in the Amazonian Tree Flora. Science 342. 1243092 (2013).

TRIFT, N. 1999. Steps to an ecology of place. In D. Massey, J. Allen and P. Sarre (ed.s), Human geographiy Today. Cambridge: Polity Press, pp. 295-322. 
Discursos e práticas à volta das árvores e suas utilidades

VASCONCELOS, J. L. De. 1897. Religiões da Lusitana. Lisboa: Imprensa Nacional.

Vasconcelos, J. L. De. 1933-1988. Etnografia Portuguesa. Lisboa: Imprensa Nacional - Casa da Moeda.

VAYDA, A. P. (ed.). 1969. Environments and cultural behavior. Garden City: Natural History Press.
VIVES, J. (ed.). 1963. Concílios Visigóticos e HispanoRomanos. Madrid: CSIC. Instituto Enrique Florez.

WILSON, A. 1992. The Culture of Nature. Cambridge MA: Blackwell. 